\section{Philips Research Reports}

DURING the period of occupation of the Netherlands by the Germans, much of the scientific work at the N. V. Philips Gloeilampenfabrieken at Eindhoven had, for obvious reasons, to be interrupted temporarily; but, in spite of all the difficulties, it never completely ceased. Now that the War is ended and the occupied countries have been liberated, Messrs. Philips Lamps Ltd. are anxious to restore the contact between the Netherlands and the rest of the world and to promote scientific co-operation. They hope to resume the publication of Philips Technical Review, which had to be stopped during the occupation, and they announce the introduction of a new scientific journal, Philips.Research Reports. The Review is to contain, as formerly, descriptions of Philips' products and their applications, being primarily intended for engineers and technically minded users of the firm's products. The Research Reports will be devoted to the results of pure research work undertaken, in many different fields, in the Company's research laboratories. The journal is to be issued bi-monthly, the six issues in one year forming a volume of about 480 pages and the first volume to be completed in 1946. The first issue is dedicated "to the memory of the firm's employees who lost their lives owing to acts of war and those who fell victim to German oppression in the years 1940-1945". The issue contains four theoretical papers dealing with the elastic after-effect and diffusion of carbon in alpha-iron, positive grid-current, the stability of lyophobic colloids, and the electric field of a vertical dipole. The price of the journal is $4 s$. a copy or one guinea a year ; copies may be obtained in Britain from Philips Lamps Ltd., Century House, Shaftesbury Avenue, London, W.C.2.

\section{H. K. Lewis \& Co., Ltd.}

IN an attractively produced book entitled "Lewis's 1844-1944. A Brief Account of a Century's Work" (London : H. K. Lewis and Co., Ltd., 1945), Messrs. H. K. Lewis give not only an excellent example of their high standard of book production, but also a fascinating history of the foundation and development of a publishing house which has attained a unique position in the intellectual life of Great Britain and other countries. The qualities of Lewis's well-known Lending Library have already been noted in Nature $(155,710 ; 1945)$; but the history of that library and of the publishing and book-selling business which accompanies it are less well known. It deserved to be told; and this book, which also gives much in. formation about the men who gradually created the services which so many medical and scientific men now enjoy, will be read with great interest. "It is hoped," says H. L. J. in his preface, "that the effort to avoid mere advertisement has been successful." That sentence is conceived in the spirit which has inspired the directors and staff of Lewis's since Henry King Lewis, in 1843 or 1844, first infused it into the small book-selling and stationery business at 15 Gower Street, the starting point of the modern Lewis's. It is interesting to learn that, in those days, readers of the Lancet who did not wish to keep that journal paid rather more than half the subscription to the Lancet and, when they had read the journal, gave it to Lewis, who displayed an advertisement, "Second Reading of the Lancet to Let" ; in this way 'second readers' were obtained, who paid the balance of the subscription. This practice is worthy of consideration nowadays, when it is often difficult to obtain sufficient copies of important journals.

From its earliest days Lewis's Library was used by distinguished medical men, and it is clear that the influence of Henry King Lewis, whose wide interests and remarkable qualities are the subject of a chapter of this book, has never faded. The history of the development of the original business to include the publishing of important books and of journals like the Clinical Journal and the British Journal of Experimental Pathology is illustrated by portraits of the many distinguished men whose books have been published by Lewis's or who have been associated with the firm in other ways. Altogether the record here presented is one of which the present directors and staff have very good reason to be proud.

\section{Eighteenth Century Russian Explorations in the Northern Pacific}

THE All-Union Geographical Society of the U.S.S.R. (Moscow) has published a small handsome volume, dated 1944, containing some newly discovered documents relating to Russian explorations and discoveries in the Pacific Ocean and North America during the eighteenth and nineteenth centuries. The first part of this book contains reports, dated 1762 and 1764 , by merchant-adventurers on the Aleutian Islands. The second part contains reports written by the members of the Russian-American Company during the period 1785-90, together with reports made by the governor-general of Siberia to the Empress Catherine on the state of trade and exploration of the Aleutian Islands and Alaska, or 'Russian America' as they were known in Russia prior to 1867. The third part consists of a diary written by N. I. Korobytzyn, a clerk of the Russian. American Company, during the first Russian round. the-world cruise of 1803-6. This diary, although written by a semi-educated man, presents a very vivid picture of the Pacific Ocean islands and of the trading conditions in Russian America and China. The book, which is entirely in Russian, is edited by A. I. Andreev, and it is provided with numerous illustrations.

\section{Visual Education and the New Teacher}

There is plenty of food for thought in the stimu. lating pamphlet under the above title prepared by $\mathbf{M r}$. G.P. Meredith, of the Visual Education Centre, Exeter (Pp. 64. 2s. 6d.), and it is to be hoped that some action may result from it. "The problem before us is the fate of the teacher under the impact of the new educational media and their ultimate effect on education." Materials and curriculum are carefully surveyed, and a plea made for the separation of teachers' functions according to their talents (for example, for academic work, class teaching, organisation, etc.) rather than as form-master or specialist. The author is concrete in his suggestions, and believes that a reasonable Dalton plan can enable the multilateral principle to be retained within one school, without the rigid 'stream' system referred to in the Spens Report. He asks, "Is the implementation of the famous 1944 Act so imperiously in motion that the unnatural barriers between grammar, modern and technical schools are unbreakable ?" Mr. Meredith maintains that the new educational media, including radio, and later, television, can only reach their full potentiality if the teacher's status is decisively raised, and by this he means not simply a matter 